\title{
The influence of grain moisture content on the efficacy of silica dust on Prostephnus truncatus (horn) (Coleoptera: bostrichidae) and Sitophilus zeamais (motsch) (Coleoptera: curculionidae)
}

\author{
Kimondo Mutambuki \\ Kenya Agricultural Research Institute, National Agricultural Research Laboratories, P.O. Box 14733-00800. Nairobi, \\ Kenya. E-mail: mutambukikimo@yahoo.com.
}

Accepted 2 January, 2013

\begin{abstract}
The effect of grain moisture content on toxicity of silica dust against adult populations of Prostephanus truncatus and Sitophilus zeamais was investigated at 8.6, 13.7, 14.1, 15.4 and 17\% moisture content levels of maize grains. Concentration levels of 0.25 to $50 \mathrm{mg} / 50 \mathrm{~g}$ maize grains were tested against $P$. truncatus and 0.25 to $7 \mathrm{mg} / 50 \mathrm{~g}$ maize grains for $S$. zeamais. The LC50 of the silica dust increased with increase in moisture content. $P$. truncatus was more tolerant to silica dust at all levels tested ranging from 0.25 to $50 \mathrm{mg} / 50 \mathrm{~g}$ compared to $S$. zeamais with lower levels of 0.25 to $7 \mathrm{mg} / 50 \mathrm{~g}$. Both insect species were able to survive at low moisture content level of $11 \%$ for 7 days with a survival rate of $89 \%$ for $P$. truncatus and $27 \%$ for $S$. zeamais without food indicating that mortality recoded was not influenced by relative humidity but silica dust activity. For $P$. truncatus, the highest mortality of $95 \%$ was at $8 \mathrm{mg} / 50 \mathrm{~g}$ and $13.6 \%$ grain moisture content whereas for $S$. zeamais the same was $96 \%$ at 2.25 $\mathrm{mg} / 50 \mathrm{~g}$ and $8.6 \%$. The results are discussed in relation to the possible use of silica dust for the control of the two insect species as an alternative to insecticides.
\end{abstract}

Key words: Stored product insect pests, maize, relative humidity, silica dust, control.

\section{INTRODUCTION}

Prostephanus truncatus (Horn) (Coleoptera: Bostrichidae) and Sitophilus zeamais (Motsch) (Coleoptera: Curculionidae) constitutes the two major pests causing serious damage on stored cob and shelled maize in a number of African countries within East, Central and Western Africa. P. truncatus is now established in 16 countries in tropical Africa, and is attributed with having increased average farm-stored maize losses from 5\% caused by conventional stored insect pests prior to its introduction as an exotic pest to $10 \%$ (Borgemeister et al., 2003). In sub-Saharan Africa weight losses of stored maize of up to $30 \%$ has been documented (Farrell and Schulten, 2002). Reports of high losses of stored maize from $P$. truncatus (Farell et al., 1996b) initiated a number of emergency control programmes and research aimed at containing the pest (Farrel et al., 1996a) that resulted in shell and treat strategy of stored maize with binary organophosphate/synthetic pyrethroid dust by small holder farmers (Golob, 1988). This was in addition to phytosanitary recommendation for maize movements and biological control with Teretrius nigrescens (Hill et al., 2003) but even with all this effort the spread is still continuing.

Sitophilus zeamais is among the major insect pests of stored maize in the tropics (Bekele et al., 1997; Asawalam and Emosairue, 2006). Damage caused by S. zeamais on maize may be extremely high. Weight loss of up to $18.3 \%$ was due to $S$. zeamais when 70 single maize kernels were exposed to ovipository adults and kept at $27^{\circ} \mathrm{C}$ and $70 \%$ relative humidity $(\mathrm{RH})$ for a period of 37 days (Adams, 1976).

Silica dusts and other inert dusts have been used for centuries to control insects, including stored product pests (Korunic, 1998). Silica dust kills by absorbing the 
oily or waxy outer cuticle layer of insect by direct contact. When the thin, waterproof layer of the epicuticle is lost, the insect loses water, and dies from desiccation (Subramanyan and Roesli, 2000; Mewis and Ulrichs, 2001). Formulations of silica dusts developed and marketed during the 1980s and 1990s contained primarily amorphous silica, and were generally more effective at lower rates compared with older products (Subramanyan et al., 1998). These commercial silica products were improved through the addition of silica gels and reduction in particle size (Subramanyan and Roesli, 2000). Although the silica aerogel are effective against many species of insects (Subramanyam et al., 1998; Fields and Korunic, 2000), their use on grain resulted in irritation to the workers because of their small particle size. In an attempt to overcome this problem of small particle size, diatomaceous earth was coated with silica aerogel resulting into 'Dryacide' with a particle size of 20 to 50 $\mu \mathrm{m}$. Dryacide was found effective against stored pests on wheat (Desmarchelier and Dines, 1987; Aldryhim, 1990).

Relative humidity is one of the most important factors affecting the efficacy of silica dust (Le Patourel, 1986; Shawir et al., 1988; Aldryhim, 1990). Insects are more vulnerable to the action of insecticidal silicas at low relative humidity and stored grain pests are more effectively controlled in grain of low moisture content (Le Patourel, 1986). Although silica dusts do not penetrate the human skin or clothes when applied, large amount of the silica dust become airborne and masks should be worn by workers to prevent inhalation. This is due to the fact that repeated exposures to large amounts of airborne crystalline silicon dioxide have been shown to be carcininogenic (IARC, 1997).

However, amorphous silica dusts are classified as having an 'unlimited' acceptable daily intake (ADI) when used as food additives and are included in a number of processed foodstuffs as anti-caking agents at levels up to $1.5 \% \mathrm{w} / \mathrm{w}$ (Anon, 1986). Silica gel has also low mammalian toxicity and Quarles (1992b) compared the toxicity of silica dust to table salt. The acute oral LD50 or Dri-die to male rats is $3160 \mathrm{mg} / \mathrm{kg}$. With these non toxic characteristics, silica dusts are known as the most promising alternative to traditional residual insecticides (Athanassiou and Korunic, 2007, Vayias and Stephou, 2009) The aim of this present work was to investigate the effectiveness of silica dust on maize against $P$. truncatus and $S$. zeamais under different humidity regimes. The effect of different relative humidity levels on the two insect pests in the presence or absence of food was also investigated.

\section{MATERIALS AND METHODS}

\section{Insect culture}

The culture medium for $P$. truncatus and $S$. zeamais was obtained from Silwood Park Insectary in the United Kingdom (UK). The two insect pests were cultured on untreated yellow maize obtained locally (Soles, Ltd., Ascot, UK). Prior to insect culturing, the maize grain was first sterilized on drying trays evenly spread in an oven at $70^{\circ} \mathrm{C}$ for two hours, cooled and then put into $2 \mathrm{~L}$ culturing jars. For $S$. zeamais, the top of the glass jars were smeared with non-sticky polytetrafluoroethylene emulsion (PTFE) (Fluon) obtained from Imperial Chemical Industries to prevent the insects from climbing and escaping. The jars were then sealed with $11 \mathrm{~cm}$ filter papers using arboreal and covered with a net held in place with rubber bands. The insect cultures were then placed in the controlled temperature at $27 \pm 2{ }^{\circ} \mathrm{C}$ and $70 \pm 5 \% \mathrm{RH}$. Insects for experiments were obtained from the culture media through sieving.

\section{Silica dust}

Silica dust (Gasil ${ }^{\circ}$ ) was obtained from Crossfield Chemicals Warrington, UK, and used in the form that was supplied by manufacturers.

\section{Maize grain}

White maize grains of mixed variety were obtained originally from Malawi and stored in a Silwood cold room maintained at $10^{\circ} \mathrm{C}$ was used for the bioassay. The maize grain was divided into 3 batches of $3 \mathrm{~kg}$ each. One of the batches was dried in an open oven $<35^{\circ} \mathrm{C}$ until the moisture content (M.C.) of about $8.6 \%$ was obtained. The maize was then kept in airtight polythene bags and stored at $5^{\circ} \mathrm{C}$ for about 4 weeks for equilibration. Other $3 \mathrm{~kg}$ batches were dried to a lower moisture content, then a calculated amount of water added and mixed with maize grains with moisture content ranging from 10.6 to $17.0 \%$. They were all sealed in airtight polythene bags and stored following the same procedure as in grains with $8.6 \%$ M.C. After three weeks, a series of moisture content determination was carried out to confirm equilibration of the grain. The following were the 6 different moisture content of grains used in the toxicity tests; 8.6, 10.6, 13.7, 14.1, 15.4 and $17.1 \%$.

\section{Determination of moisture content}

The moisture content determination method for the grain used in the bioassay was the Association of Official Analytical Chemists air oven method described by Howitz (1970). A random sample of maize grain containing $14 \mathrm{~g}$ (about 25 kernels) was taken and ground in coffee grinder for about $30 \mathrm{~s}$. Two grams of the well mixed sample was weighed using an Oetling ${ }^{\circledR}$ microbalance in aluminum dishes which had been previously dried in an oven provided with an opening for ventilation and maintained at $130^{\circ} \mathrm{C}$ for $1 \mathrm{~h}$. The weighed uncovered dishes plus the sample and the covers were then dried in the oven still maintained at $130^{\circ} \mathrm{C}$ for $1 \mathrm{~h}$. The dishes were covered while still in the oven using tongs and transferred to a desiccator for cooling to room temperature. The final weight was taken and the difference in weight expressed as a percentage of initial weight showing the loss in moisture. For each sample, 5 replicates were used for moisture determination.

\section{The Bioassay}

Bioassay of the $\mathrm{Gasil}^{\circledR}$ at different grain moisture contents was carried out by weighing $50 \mathrm{~g}$ of maize into glass jars. Different concentrations of silica dust was added and the grain admixed thoroughly by shaking and rotating for about 2 min to allow uniform distribution. The glass jars were then sealed with $7 \mathrm{~cm}$ filter paper and a lid. The jars were left for $48 \mathrm{~h}$ at room temperature of $25^{\circ} \mathrm{C}$ to equilibrate. Grain moisture contents were determined at the beginning of each bioassay from sub samples taken from each 
Table 1. Saturated salt solutions for humidity control at $25^{\circ} \mathrm{C}$

\begin{tabular}{lc}
\hline Salt & Relative humidity (\%) \\
\hline $\mathrm{KCl}$ & 84 \\
$\mathrm{NaCl}$ & 75 \\
$\mathrm{NaBr} .2 \mathrm{H}_{2} \mathrm{O}$ & 58 \\
$\mathrm{Mg}(\mathrm{NO})_{3} 2 \mathrm{H}_{2} \mathrm{O}$ & 53 \\
$\mathrm{KCO}_{3} 2 \mathrm{H}_{2} \mathrm{O}$ & 43 \\
$\mathrm{MgCl}_{2} 6 \mathrm{H}_{2} \mathrm{O}$ & 33 \\
$\mathrm{LiClH}_{2} \mathrm{O}$ & 11 \\
\hline
\end{tabular}

batch. Thirty, 3 to 5 weeks old unsexed adults of $P$. truncatus and $S$. zeamais were then introduced into each jar, resealed, returned to room temperature at and mortality was assessed after 7 days. Ranging tests were carried out using 4 varying concentrations of the dust in each moisture content until a mortality of between 5 and $100 \%$ was achieved; mortality was defined as those insects that showed no visible response within $60 \mathrm{~s}$ even when a camel hair brush was run over them. Abbotts formula (1925) was used to correct for control mortality where necessary and the data analyzed by logic analysis in GLIM. LC50 and 95\% fiducial limits and slopes of $\log$ (Conc.)/probit regression lines were calculated (Finney, 1971).

\section{Effect of relative humidity on insect survival}

The evaluation of insect survival was carried out under different humidity conditions. Different saturated salt solutions of known RH equilibration at $25^{\circ} \mathrm{C}$ were used (Young, 1967) (Table 1). Weighed amount of the salts were dissolved in known volumes of water and put in open circular plastic dishes to give excess salt and hence saturated solutions. These were then placed in airtight plastic boxes measuring $25 \times 15 \mathrm{~cm}$ and $9 \mathrm{~cm}$ deep. The plastic boxes were made more airtight by sealing the gap between the lid (top) and the main box by plastic tape. The boxes were then placed at room temperature of $25^{\circ} \mathrm{C}$ for $48 \mathrm{~h}$ to allow the salt solutions to equilibrate. Afterwards, insects contained in petridishes measuring $5 \mathrm{~cm}$ diameter and $2 \mathrm{~cm}$ deep smeared with fluon near the top and covered with perforated lids were introduced. The fluon was used to deter S. zeamais from climbing out and the lid presented both insects from flying out particularly $P$. truncatus. In the first experiment, the insects were not provided with any food. In the second one, they were provided with $2 \mathrm{~g}$ of broken maize grains. All the Petri dishes with insects and in airtight plastic containers were placed at $25^{\circ} \mathrm{C}$ room temperature. There were 5 replicates for each relative humidity. Mortality was assessed after 7 days at various $\mathrm{RH}$ regimes.

\section{RESULTS}

\section{Toxicity of silica dust on P. truncatus and S. zeamais}

Silica dust has insecticidal efficacy against $P$. truncatus and $S$. zeamais were able to pick up silica dust on maize grain resulting in mortality. Analysis of the variance in GLIM showed that in both pests there was no significance difference $(P>0.05)$ between the interaction of moisture content and log concentration on insects mortality. However, there were significant differences $(P<0.05$ in mortality in grains with different moisture content and varying concentrations of dusts as shown in Table 3. LC50 values of the two insect pests at different grain moisture content were derived from common slope regression (Table 4). There was a marked increase in the amount of silica dust required to kill $50 \%$ of the population in the different concentrations applied as shown in Table 2. Again, the amount of dust concentration required to obtain 5 to $100 \%$ mortality of the population in S. zeamais was markedly lower than that required for a similar population of $P$. truncatus. In $P$. truncatus the concentration of dust required to cause over $50 \%$ mortality of the population increased about 3fold from grain with $8.5 \%$ moisture content to that having $17 \%$ M.C. The same table further shows that there was about a 40-fold increase in S. zeamais in grains with similar moisture content. In both cases, LC50 increased with increase in grain moisture content. Very low amounts $(0.25 \mathrm{mg} / 50 \mathrm{~g})$ of silica dust was able to obtain mortality over $80 \%$ of $S$. zeamais in maize grain with $8.6 \%$ M.C. Similar amount of dust could only result in $4 \%$ mortality of $P$. truncatus. S. zeamais was therefore more susceptible to silica dust than $P$. truncatus.

\section{Effect of relative humidity on insect survival}

The different relative humidities had different effect on the mortality of two insect species. $P$. truncatus whether in the presence or absence of food was more tolerant in low humidities than $S$. zeamais (Table 5). The highest mortality recorded in $P$. truncatus was $11 \%$ without food compared to $4 \%$ while provided with food. This was recorded at low humidity levels of $11 \% \mathrm{RH}$. Overall, there was very little difference in mortality between the lowest and the highest \% RH (1 to 11\%) in P. truncatus while provided with or without food. Analysis of deviance, however, showed that although there was no significant difference between the pest while in the presence or absence of food, there was a significant difference within those provided with food and those without food ( $p, 0.025)$ (Table 6). Conversely, S. zeamais was affected by reduced relative humidities recording 66 and $67 \%$ mortality while without food and with food respectively, at $11 \% \mathrm{RH}$. As further shown in Table 5, there was increased mortality as humidity decreased when $S$. zeamais was not provided with food. There was a significant difference between the insect sets with and without food but not within the sets $(p, 0.05)$ (Table 6). $P$. truncatus was more tolerant at the lowest relative humidity with or without food when compared to $S$. zeamais (Table 5)

\section{DISCUSSION}

The bioassay findings clearly showed that the LD50 of 
Table 2. Toxicity of silica dust to $P$. truncatus and $S$. zeamais at different moisture content (M.C) at $25^{\circ} \mathrm{C}$.

\begin{tabular}{|c|c|c|c|}
\hline Pest & M.C. (\%) & $\begin{array}{c}\text { Concentration } \\
(\mathrm{mg} / 50 \mathrm{~g})\end{array}$ & $\begin{array}{c}{ }^{*} \text { Mortality } \\
(\%)\end{array}$ \\
\hline \multirow{24}{*}{$\begin{array}{l}P . \\
\text { truncatus }\end{array}$} & \multirow{4}{*}{8.5} & 0.25 & 4 \\
\hline & & 0.5 & 9.3 \\
\hline & & 1.15 & 26 \\
\hline & & 2.25 & 94.6 \\
\hline & \multirow{4}{*}{10.7} & 0.65 & 4.7 \\
\hline & & 1.25 & 5.3 \\
\hline & & 2.5 & 11.2 \\
\hline & & 5 & 92.7 \\
\hline & \multirow{4}{*}{13.6} & 3.5 & 46 \\
\hline & & 5 & 59.3 \\
\hline & & 6.5 & 80 \\
\hline & & 8 & 95.3 \\
\hline & \multirow{4}{*}{14.1} & 4 & 55.4 \\
\hline & & 6 & 61.4 \\
\hline & & 8 & 64.7 \\
\hline & & 10 & 85.4 \\
\hline & \multirow{4}{*}{15.4} & 3.5 & 43.3 \\
\hline & & 5 & 46 \\
\hline & & 6.5 & 59.3 \\
\hline & & 8 & 95.3 \\
\hline & \multirow{4}{*}{17} & 4.5 & 7.3 \\
\hline & & 10 & 36 \\
\hline & & 25 & 71.4 \\
\hline & & 50 & 86.7 \\
\hline \multirow{20}{*}{ S. zeamais } & \multirow{4}{*}{8.6} & 0.25 & 81.3 \\
\hline & & 0.5 & 89.3 \\
\hline & & 1.15 & 86 \\
\hline & & 2.25 & 96 \\
\hline & \multirow{4}{*}{13.6} & 0.25 & 13.4 \\
\hline & & 0.65 & 46.7 \\
\hline & & 1.25 & 53.4 \\
\hline & & 3.5 & 95.4 \\
\hline & \multirow{4}{*}{14.1} & 0.25 & 12.6 \\
\hline & & 0.75 & 18 \\
\hline & & 1.5 & 90 \\
\hline & & 3.5 & 95.3 \\
\hline & \multirow{4}{*}{15.4} & 0.25 & 54.7 \\
\hline & & 0.75 & 54.7 \\
\hline & & 1.5 & 57.3 \\
\hline & & 3.5 & 93.3 \\
\hline & \multirow{4}{*}{17} & 1.5 & 1.3 \\
\hline & & 3.5 & 4 \\
\hline & & 5 & 88 \\
\hline & & 7 & 96 \\
\hline
\end{tabular}

* Mortality- means of 5 replicates.
Table 3. Analysis of deviances on toxicity of Gasil on P.truncatus and S. zeamals

\begin{tabular}{lccccc}
\hline Source & SS & df & MS & F & P \\
\hline \multicolumn{7}{c}{$P$. Truncatus } \\
Ldose & 532 & 5 & 106.4 & 6.15 & * \\
Let & 89.09 & 5 & 17.818 & 1.03 & NS \\
Residue & 207.49 & 12 & 17.29 & & \\
Total & 2041.6 & 23 & & & \\
Ldose & 492.2 & 1 & 492.2 & 27.89 & * \\
Set & 1547 & 5 & 309.4 & 17.53 & * \\
Ldose.Set & 55 & 5 & 55 & 3.12 & \\
Residue & 190.42 & 11 & 17.65 & & \\
Total & 2504 & 22 & & & \\
\hline
\end{tabular}

${ }^{*} p<0.05$.

silica dust increased with increasing grain moisture content for both insect species. These results support the findings of le Patourel (1986) and Shawir et. al. (1988), they showed that the insecticidal activity of amorphous silica admixed with grain decreases rapidly as grain moisture is raised above $14 \%$. Susceptibility of both insects to silica dust was not unusual as it has been shown that by crawling among kernels, grain infesting beetles cannot avoid some degree of abrasion (Subramanyan and Roesli, 2000). Under these conditions, the most effective dust desiccants have been non abrasive; highly sorptive powders particularly silica aerogel whose absorption of insect wax at ordinary temperatures depends entirely on the physical properties of the sorptive dust (Ebeling, 1971).

For S. zeamais the activity of silica dust decreased only after the grain moisture content rose above $15 \%$ M.C. As shown in Table 2, what was surprising was the amount of dust required to control $50 \%$ population of $P$. truncatus as compared to $S$. zeamais was above $10 \%$ at any level of moisture content. This difference in the LC50 values suggests difference either in behavior, physical and chemical properties of the cuticle in both species. It may be attributed primarily to insect body size and surface area (Elbeing, 1971; Quarles, 1992b), however, both insects are of similar size. One possible cause is the greater activity of $S$. zeamais within the admixed grain picking a lot of dust as they move within the grains. $P$. truncatus on the other hand immediately after introduction into the grain moved to the bottom of the glass jar and soon bored into the grain thereby decreasing the chances of picking up the dust. Mortality of $P$. truncatus in grains with moisture content above $8.6 \%$ M.C increased only at high concentrations above 4 $\mathrm{mg} / 50 \mathrm{~g}$ where the excess dust which could not adhere to grains accumulated at the bottom of the jars. A possible explanation for both insect species being highly susceptible to silica dust at the lowest grain moisture 
Table 4. Toxicity of Gasil to $P$. truncatus and S. zeamals at different maize moisture content at $25^{\circ} \mathrm{C}$ after 7 days of exposure

\begin{tabular}{lcccc}
\hline Pest & Moisture content & $\begin{array}{c}\text { Parallel regression } \\
\text { logdosellogic (mortality) }\end{array}$ & LC50 (mg/kg) & LC95 \\
\hline \multirow{3}{*}{ P. truncatus } & 8.6 & $\mathrm{Y}=0.52+4.82 \mathrm{x}$ & 1.3 & $1.2(1.4)$ \\
& 10.6 & $\mathrm{Y}=2.87+4.82 \mathrm{x}$ & 3.9 & $3.5(4.3)$ \\
& 13.7 & $\mathrm{Y}=2.43+4.82 \mathrm{x}$ & 3.2 & $2.9(3.5)$ \\
& 14.1 & $\mathrm{Y}=2.9+4.82 \mathrm{x}$ & 3.99 & $3.6(4.4)$ \\
& 15.4 & $\mathrm{Y}=2.99+4.92 \mathrm{x}$ & 4.2 & $3.7(4.6)$ \\
& 17 & $\mathrm{Y}=5.14+4.82 \mathrm{x}$ & 11.7 & $11.7(12.9)$ \\
S. zeamais & 8.6 & $\mathrm{Y}=4.21+4.9 \mathrm{x}$ & 0.1 & $0.1(0.2)$ \\
& 10.6 & $\mathrm{Y}=1.94+4.9 \mathrm{x}$ & 0.4 & $0.4(0.4)$ \\
& 13.7 & $\mathrm{Y}=0.29+4.9 \mathrm{x}$ & 0.9 & $0.8(0.1)$ \\
& 14.1 & $\mathrm{Y}=0.44+4.9 \mathrm{x}$ & 0.8 & $0.7(0.7)$ \\
& 15.4 & $\mathrm{Y}=1.07+4.9$ & 1.7 & $1.5(1.8)$ \\
\hline
\end{tabular}

Table 5. Effect of relative humidity on survival of $P$. truncatus with and without food.

\begin{tabular}{cccc}
\hline $\begin{array}{c}\text { With food } \\
(\% \mathrm{RH})\end{array}$ & $\begin{array}{c}\text { Mortality } \\
(\%)\end{array}$ & $\begin{array}{c}\text { Without food } \\
(\% \mathrm{RH})\end{array}$ & $\begin{array}{c}\text { Mortality } \\
(\%)\end{array}$ \\
\hline \multicolumn{4}{c}{ P. truncatus } \\
84 & 1 & 84 & 1 \\
75 & 2 & 75 & 4 \\
58 & 0 & 58 & 1 \\
53 & 0 & 53 & 2 \\
43 & 2 & 43 & 5 \\
33 & 3 & 33 & 3 \\
11 & 4 & 11 & 11 \\
\multicolumn{4}{c}{ S. zeamais } \\
84 & 0 & 84 & 1 \\
75 & 0 & 75 & 1 \\
58 & 1 & 58 & 7 \\
53 & 3 & 53 & 13 \\
43 & 1 & 43 & 15 \\
33 & 0 & 33 & 28 \\
11 & 67 & 11 & 63 \\
\hline
\end{tabular}

content is that it is known that the drier the grain the harder it becomes to bore through necessitating both pests to wonder around searching for susceptible kernels and in the process picking more dust relative humidity levels pertaining in equilibrium with The main reason for the effectiveness of dust in the grain with low moisture content probably resides in the such grain. The dusts are effective by disrupting the water retaining properties of the insect epicuticular layers Mewis and Ulrichs, 2001) and and it follows that the insect will desiccate and die more rapidly at lower relative humilities than at high ones.

The nature of the epicuticular lipid and the ability of the
Table 6. Analysis of deviance on effect of relative humidity on survival of $P$. truncatus and $S$. zeamals.

\begin{tabular}{|c|c|c|c|c|c|}
\hline Source & SS & df & MS & $\mathbf{F}$ & $\mathbf{P}$ \\
\hline \multicolumn{6}{|c|}{ P. truncatus } \\
\hline \multicolumn{6}{|l|}{ Ldose } \\
\hline Set & 4.35 & 1 & 4.35 & 9.1 & * \\
\hline Ldose.Set & 0.492 & 1 & 0.492 & 1.03 & \\
\hline Residue & 3.818 & 8 & 0.477 & & \\
\hline Total & 19.22 & & 11 & & \\
\hline \multicolumn{6}{|c|}{ S. zeamals } \\
\hline Ldose & 355.9 & 1 & 355.9 & 185.9 & * \\
\hline Set & 8.171 & 1 & 8.171 & 4.27 & NS \\
\hline Ldose.Set & 11.06 & 1 & 11.06 & 5.78 & * \\
\hline Residue & 13.4 & 7 & 1.94 & & \\
\hline Total & 388.5 & 10 & & & \\
\hline
\end{tabular}

insect to compensate for water and epicuticular lipid loss (le Patourel, 1986) may also be an important factor. In addition, it was further shown that Sitophilus species which had its wax layer protected by a cement layer had a lower rate of desiccation by sorptive dusts when compared to Rhyzopertha dominica F. with a softer wax. $R$ dominica belong to the same family as $P$. truncatus further suggesting that so long as there is dust for the latter pest to pick up, chances of a high mortality of $P$. truncatus may be realized possibly similar to that of $S$. zeamais.

This work also suggests that there is a high possibility of both insects being particularly tolerant to silica dust admixed with maize at high moisture content above $15 \%$ and all levels of relative humidity. This is in agreement with le Patourel (1986) and Shawir et al. (1988) who 
showed that Sitophilus spp. may be particularly tolerant to amorphous silica with relative high moisture content. However, the storage condition of maize is $13.5 \%$ M.C referred to as the safe storage moisture content which is in equilibrium with $70 \% \mathrm{RH}$ and above this moisture content the silica is not so effective.

The two species were able to survive with or without food at low humidity levels. S. zeamais was, however, not able to survive at extremely low humidity of $11 \% \mathrm{RH}$.

The tolerance of the two pests to low relative humidities without food even for a short period suggests the mortality resulting from sorptive dusts in the bioassay may have had no relationship with low amounts of water or metabolic resulting from ingested food. This contrasts with work carried out by Vrba et al. (1983) who found out that death of $T$. confusum exposed to silica aerogel 380 was delayed when insects were provided with food. Le Patourel and Zhou (1990) similarly found that cockroaches provided with drinking water were less susceptible to silica dusts.

During the last two decades, concern has been raised on environmental contamination by pesticides, together with more specific problems associated with insecticides. This has led to increased interest leading to more research on diatomaceous earth with the need to identify alternative methods of control (Fields and Korunic, 2000; Mewis and Ulrichs, 2001; Arthur, 2003).

Sorptive silica dust formulation which has been found in this work to be effective in the control of the two insect species at low moisture content can be adopted for their control. Moreover, silica gels have low mammalian toxicity (Quarles, 1992b) and their suitability for the control of these two species both in small and large grain facilities should be further explored. It is also essential to evaluate formulations that can be effective at lower dosage rates.

\section{ACKNOWLEDGEMENTS}

The author would like to extend profound thanks to Kenya Agricultural Research Institute (KARI) and Department for International Development (DFID) for their financial support to this study.

\section{REFERENCES}

Abbot WS (1925). A method of computing the effectiveness of an insecticide. J. Econ. Entomol. 18:265-267.

Adams JM (1976) Weight loss caused by development of Sitophilus zeamais Motsch in maize. J. Stored Prod. Res. 12:269-272.

Aldryhim YN (1990) Efficacy of Amorphous silica dust, dryacide, against Tribolium confusum Duv. and Sitophilus granaries (L.) (Coleoptera: Tenebrionidae and Curculionidae). J. Stored Prod. Res. 26:207-210.

Anon (1986). Keep it Flowing Conditioning and Anticking aid Ref, M691.J. Crossfield and Sons Ltd., Applied Silica Div., Warrington, Cheshire, U.K.

Arthur FH (2003). Optimization of inert dusts used as grain protectants as a residue surface treatments. In: Credland PF, Armitage DM, Bell $\mathrm{CH}$, Cogan PM, Highley E (Eds) (2002). Proceedings of $8^{\text {th }}$ International Conference on Stored-Product Protection. 22-26 July.
York, UK. CAB.

Asawalam EF, Emosairue SO (2006). Comparative efficacy of Piper guineense (Schum and Thonn) and pirimiphos methyl on Sitophilus zeamais (Motsch.) Trop.Subtrop. Agroeco. 6:143-148.

Athanassiou CG, Korunic Z (2007). Evaluation of two new diatomaceous earth formulations enhanced with abamectin and bitterbarkomysin, against four stored grain beetle species. J. Stored Prod. Res. 43:468-473.

Bekele AJ, Obeng-Ofori D, Hassanali A (1997). Evaluation of Cimum kenyense (Ayobangira) as a source of repellents toxicants and protectants in storage against three major stored products insect pests. J. Appl. Entomol. 121:169-173.

Borgemeister C, Holst N, Hodges RJ (2003). Biological control and other pest management options for larger grain borer Prostephanus truncatus. pp.311-328 in Neuenshwander, P. Borgeimeister, C., \& Langewald, J. (Eds) Biological control in IPM systems in Africa. Wallingford Oxon, CAB International.

Desmarchelier JM, Dines JC (1987). Dryacide treatment of stored wheat: its efficacy against insects and after processing. Aust, J. Exp. Agric. 27:309-312.

Ebeling W (1971). Sorptive dusts for pest control. Ann. Rev. Entomol. 16:1-61.

Farrel G, Gratehead AH, Hill MG, Kibata GN (Eds) (1996a). Management of farm storage pests in East and Cental Africa. Proceedings of the East of the East and Central African storage Pest Mnanagement Workshop, 14-19 April 1996, Naivasha, Kenya. International Institute of Biological Control (IIBC), Ascot, Berks.

Farrel G, Hill MG, Nangayo FLO, Stabrawa A (1996b). A review of investigations to improve pest management of stored maize in smallholder farm in Kenya. Int. Pest Manage. Rev. 1:251-263.

Farrel G, Schulten GGM (2002) Larger grain borer in Africa: a history of efforts to limit its impact. Int. Pest. Manage. Rev. 7:67-84.

Fields PG, Korunic Z (2000). The effect of grain moisture content and temperatures on the efficacy of diatomaceous earth from different geographical locations. J. Stored Prod. Res. 36:1-13.

Finney DJ (1971). Probit analysis, $3^{\text {rd }}$ ed. Cambridge University Press. pp. 88-99.

Golob, P (1988). Chemical control of the larger grain borer pp. 53-69 in Schulten, G.G.M. \& Toet, A.J. (Eds) Report II technical papers presented at the workshop. Workshop on the containment and control of the larger grain borer, Arusha. Tanzania, (16-21) May 1988). Ministry of Agriculture and Livestock development, Tanzania, and Food and Agriculture Orgamisation of the United Nations, Rome, Italy.

Hill MG, Nangayo FLO, Wright DW (2003). Biological control of the larger grain borer Prostephanus truncatus (Coleoptera:Bostrichidae) in Kenya using predatory beetle Teretrius nigrescens (Coleoptera: Histeridae). Bull. Entomol. 93:299-306.

Howitz W (1970). Official methods of analysis of the Association of Official Analytical Chemists. 11th edn. AOAC, Washington D.C.

InternationalAgency for Research on Cancer (IARC) (1997). Silica, some silicates, coal dusts and para-aramid fibrils. IARC Working Group on the Evaluation on Carcinogenic Risks to Human, Lyon, France.68:506.

Korunic Z (1998). Diatomaceous earths, a group of natural insecticides. J. Stored Prod. Res. 34:87-97.

Le Patourel GNJ (1986). The effect of grain moisture content on toxicity of a sorptive silica dust to four species of grain beetle. J. Stored Prod. Res. 25(2):65-72.

Le Patourel GNJ Zhou JJ (1990). Action of amorphous silica as an additive to dust formulations of insecticides for stored pest control. J. Stored Prod. Res. 9:225-234.

Mewis L, Ulrich Ch (2001). Action of amorphous diatomaceous earth against different stages of the stored product pests: Tribolium confusum (coleopteran: Tenebrionidae), Sitophilus granaries (Coleoptera: Curculionidae), Plodia interpunctella (Lepidoptera: Pyralidae). J. Stored Prod. Res. 37:153-164.

Quarles W (1992b). Silica gel for pest control. The IPM Practioner. 14:111.

Shawir M, le Patourel GNJ, Moustafa FI (1988). Amorphous silica as an addition to dust formulations of insecticides for stored grain pest control. J. Stored Prod. Res. 24:123-130. 
Subramanyan Bh, Madamnchi N, Norwood S (1998). Effectiveness of Insecto applied to shelled maize against maize stored product insect larvae. J. Stored Prod. Res. 91:280-286.

Subramanyan BH, Roesli R (2000). Inert dust. In: Subramanyam, Bh.; Hagatrum, D. W. (eds). Alternatives to pesticide in stored-products IPM. Kluwer Academic PublishersNorwell, Massachusetts. pp. 321380.

Vayias BJ, Stephou VK (2009). Factors affecting the insecticidal efficacy of the enhanced diatomaceous earth formulation against three stored insect species. J. Stored Prod. Res. 45:226-231.
Vrba CH, Arai HP, Nosal M (1983). The effect of silica aerogel on the mortality of Trifolium confusum (Dual) as a function of exposure time and food deprivation. Ent, Soc. Lond. Ser B 134:163-181.

Young JF (1967). Humidity control in the laboratory using salt solutionsa review. J. Appl. Chem. 17:241-245. 